\title{
KRITICKÉ ČÍTANIE LITERATÚRY VÍŤAZOSLAVA HRONCA ${ }^{1}$
}

V texte sa analyzuje kritické čítanie literatúry Vít’azoslava Hronca, ktoré zaberá dôležité miesto nielen v jeho celkovej literárnej činnosti, ale aj v literatúre vojvodinských Slovákov. Prvé literárnokritické intepretácie aktuálnej súdobej slovenskej vojvodinskej básnickej tvorby Hronec publikoval v 60. rokoch 20. storočia a odvtedy prakticky dodnes sa svojím kritickým čítaním literatúry usiluje usmerňovat' a skvalitňovat' celkovú literárnu tvorbu vojvodinských Slovákov. Dôležité sú zvlášt' jeho antológie slovenskej vojvodinskej poézie a obsiahle literárnohistorické predslovy k ním, ktoré možno čítat' ako svojrázne dejiny slovenskej vojvodinskej poezie. Základné metodologické východisko Vítazoslava Hronca bolo zo začiatku inšpirované fenomenológiou, no neskôr, najmä v postmodernom tvorivom období na prelome storočia, jeho kritické čítanie literatúry poznačil esejistický výraz a široký kulturologický zorný uhol, v ktorom naplno prišlo k slovu autorova výnimočná erudícia a sluch pre tep doby. esej.

Kl'účové slová: Vít’azoslav Hronec, kritické čítanie literatúry, antológia, fenomenológia,

Náznaky Hroncovho ambiciózneho úsilia o revalorizáciu a ustanovovanie slovenskej vojvodinskej literarnej tradície vidno už v jeho prvých literárnokritických textoch uverejňovaných koncom 60 . rokov 20. storočia v Novom živote, v ktorých dôkladne interpretoval poéziu prakticky všetkých vtedajších najvýznamnejších slovenských vojvodinských spisovatel’ov (Ján Labáth, Michal Babinka, Pal'o Bohuš, Juraj Tušiak, Viera Benková...), usilujúc sa pritom súbežne aj teoreticky definovat' svoje náhl'ady na literatúru a literárnu kritiku. Tieto Hroncove literárnokritické texty (Poézia '66, Klavír v žite, Vyzliekanie z krvi, Len jeden kruh, Na začiatku: príst' na meno inej básnickej tradicii, Konfrontovanie dvoch poetik, Rozhraničovanie, Fragment o klasicizujúcej poetike), neskôr publikované v knihe kritík Za poetikou (Hronec, 1979) sú poznačené intelektuálnou revoltou mladého spisovatela, vyvolanou jeho uvedomovaním si nízkej úrovne súdobej beletristickej a literárnokritickej tvorby vojvodinských Slovákov a usmernenou na jej

svetlika@ptt.rs

Rad je nastao u okviru republičkog projekta (br. 178017) Diskursi manjinskih jezika, književnosti i kultura u jugoistočnoj i srednjoj Evropi. 
modernizáciu a profesionalizáciu, na búranie lokálnych či enklávových medzí, na zapájanie sa literatúry vojvodinských Slovákov do širších, celoslovenských, juhoslovanských a svetových literárnych trendov a na literárnokritické sústred’ovanie sa výlučne na literárne, respektíve estetické témy a problémy, ktoré by pritom nebolo zatažené, $-\mathrm{v}$ tom čase $\mathrm{v}$ slovenskej vojvodinskej literárnej kritike bežným javom - biografizmom, sociologizmom, psychologizmom... To, čo Hronca už na začiatku svojej literárnej činnosti v slovenskej vojvodinskej literatúre zrejme najviac rozčul'ovalo a provokovalo bol nezodpovedný a neprofesionálny vzt’ah spisovatel'ov a literárnych kritikov $\mathrm{k}$ vlastnej tvorbe; “pajtášstvo", politikánstvo, osobná zaujatost' a najmä zameranost' na nepodstatné, neliterárne problémy v literárnej kritike. Hroncovo kritické čítanie literatúry v jeho prvých literárnokritických príspevkoch bolo však poznačená značným metodologickým eklekticizmom, $v$ ktorom sa najviac cítil vplyv tzv. novej kritiky a najmä spisovatel'a a literárneho kritika Thomasa Stearnsa Eliota. Podnetost' tohto novopozitivizmu či amerického formalizmu, priama alebo sprostredkovaná srbskou literárnou kritikou, sa prejavuje predovšetkým ako Hroncova literárnokritická sústredenost' na samotný literárny text, na jeho close reading, čiže verné, objektívne kritické čítanie, bez mimoliterárneho zretel'u či kontextu (biografia, sociológia, psychológia, ideológia...).

Aj ked' sa Hronec jednoznačne zasadzoval za objektívnejší prístup v literárnej kritike, čo znamená že bol jednoznačne proti impresionizmu a voluntarizmu, vo svojom kritickom čítaní literatúry predsa nebol zástancom rigidného scientizmu, lebo si už vtedy myslel, a pri tom postoji zostal prakticky dodnes, že prírodovednými metódami sa nedá preniknút do viacvýznamového a metafyzického rozmeru literárneho textu. Jeho celková koncepcia literatúry a jej kritického čítania je teda v podstate subjektívna, teda zaujatá, čo sa prejavuje už napríklad aj tým, že dôsledne uprednostňuje klasicizujúcu pred romantizujúcou poéziou. Možno v tom vidiet' predovšetkým Hroncovu nadväznost' na súdobí srbský literárny kontext, v ktorom delenie na klasicizujúcu a romantizujúcu literatúru, predovšetkým poéziu, bolo v 60 . rokoch minulého storočia nanajvýš aktuálne, na rozdiel povedzme od slovenskej literatúre, v ktorej sa takáto "rozčesnutost" literatúry v jej kritickom čítaní nevyskytovala a neuplatňovala. V tomto kontexte možno zvlášt' podčiarknút' meno významného srbského básnika a literárneho kritika Miodraga Pavlovića, ktorého "klasicizujúca" poézia, ale najmä koncepcia literatúry prezentovaná v knihe Antologija srpskog pesništva od XIII do XX veka, podstatne vplývali na Vít’azoslava Hronca a na jeho prehodnocovanie slovenskej vojvodinskej, a neskôr i celoslovenskej poézie.

Z takejto perspektívy odpozorované potom aj Hroncovo prvé sústavné kritické čítanie, čiže interpretovanie a hodnotenie slovenskej vojvodinskej poézie, prezentované roku 1974 v knihe Poézia vojvodinských Slovákov (od 18. do 20. storočia) (Hronec, 1974), ponajprv v rozsiahlom "historizujúcom" predslove, ale i v samotnom výbere básní a básnikov zaradených do antológie, vnímame ako syntézu jeho dovtedajšieho (kritického) čítania literatúry, čiže ako stavanie a 
upevňovanie základu, na ktorom tento, $\mathrm{v}$ tom čase mladý spisovatel' začínal budovat' nielen svoj básnický prehovor, ale aj svoju celkovú literárnu koncepciu, poetiku. Hronec si teda už vtedy naplno uvedomoval vlastnú účast' v konštituovaní básnickej tradície vojvodinských Slovákov, lebo podl’a jeho slov „každá generácia spisovatel'ov v okamihu, ked'si začina uvedomovat' dedičstvo svojich predchodcov, začina hl'adat' aj svoje miesto v konštelácii známych i neznámych mien svojej literárnej histórie“. Príznačné je však, že je Hroncov postoj k tejto tradícii, prezentovaný jednak priamo $\mathrm{v}$ obsiahlom literárnokritickom respektíve literárnohistorickom Predslove, jednak nepriamo vo výbere básní do antológie, výrazne kritický, neraz až príkro devastujúci, no predsa pritom vždy sprevádzaný aj autorovým pevným predsavzatím takýto deprimujúci stav slovenskej vojvodinskej poézie menit', vylepšovat' a zvel'ad'ovat'. Touto knihou sa vlastne začala Hroncova celoživotná, zrejme osudová, krížiacka výprava, na momenty nadobúdajúca dokichotský či sizyfovský nádych, s ambicióznym ciel’om vyčistit' a prevetrat' "zadubenú" a "potuchlinou nasiaknutú" literatúru vojvodinských Slovákov, podriemkávajúcu vo svojej okrajovosti, malosti a sebestačnosti. Z dnešného nadhl'adu je už celkom viditel'né, že táto Hroncova prvá revalorizácia slovenskej vojvodinskej poézie predznamenala, ale zároveň i črtala novú, modernejšiu koncepciu slovenskej vojvodinskej poézie, určovanú prísne stanovenými estetickými kritériámi a vzpierajúcu sa pritom najrozličnejším, poézii nevlastným, populistickým, nacionálnym a ideologickým nátlakom. To čo však v takomto Hroncom projektovanom, a potom i vo výbere prezentovanom obraze slovenskej vojvodinskej poézie bolo z aspektu jeho celkovej literárnej koncepcie iste najproblematickejšie, no na čom Hronec prakticky dodnes trvá, je jej subjektivnost' a najmä jednostranost'; jednoznačné uprednostňovanie klasicizujúceho pred romantizujúcim rozmerom poézie. Takýto Hroncov binárny koncept literatúry, predovšetkým poézie, bol zrejme produkovaný vplyvom dominantných literárnych prúdení v súdobej srbskej, ale i svetovej poézii, a ako taký bol v nesúlade s vtedy, teda začiatkom 70. rokov 20. storočia, tradičným, vo svojej podstate romantizujúcim konceptom slovenskej vojvodinskej poézie, kulminujúcim v Bohušovej priam kultovej zbierke básní Hviezdne proso. Evidentné je však, že si vtedajšiu outsidersku pozíciu preferovaného konceptu literatúry, a zároveň aj vlastnú dostatočne neetablovanú pozíciu v literárnom živote vojvodinských Slovákov Hronec naplno uvedomoval, takže v tejto svojej, podmiečne povedané, prvej fáze prehodnocovania slovenskej vojvodinskej poézie predsa postupoval obozretne a sčasti i ústretovo. Vidno to najmä v tom, že tento svoj uprednostnený model poézie, respektíve literatúry nezhodnotil jednoznačne ako ,lepši “, ale len ako modernejší, teda priliehavejší požiadavkám „,̌loveka 20. storočia". Na kompromis a čiastočne i ústup bol však Hronec prinútený aj priamou zásahou cenzúry, čiže zákazom, ako to on neskoršie eufemisticky pomenoval „vyššej sily“ do tohto výberu zaradit’ ideologicky problematické verše Martina Tomana Banátskeho a Juraja Mučajiho. Okrem toho, Hronec bol podla vlastných slov prinútený aj na svojráznu hodnotiacu nedôslednost', lebo v prvej časti tohto 
výberu, teda pri ustanovovaní dostatočne nevyvinutej básnickej tradície vojvodinských Slovákov v 19. storočí a v prvej polovici 20. storočia uprednostnil literárnohistorické pred estetickými kritériámi. Práve z tohto dôvodu aj táto kniha má podla mienky jej autora dvojitý charakter - v prvej časti je chrestomatia a v druhej antológia.

Logickým pokračovaním antológie slovenskej vojvodinskej poézie bola Antológia slovenskej poézie 20. storočia (Hronec, 1986), ktorou Hronec končí podmienečne povedané prvé obdobie kritického čítania a prehodnocovania slovenskej poézie, spôsobeného predovšetkým potrebou vybudovat' pevné základy vlastného poetického "domu”, ale pritom zrejme aj vyprovokovaného neexistenciou antológie slovenskej poézie 20 . storočia, ktorá by bola ideologicky nezatažená a zostavená len podla literárnych či estetických princípov. Aj Hroncova antológia sa síce nemohla celkom vyhnút' neestetických kritérií, lebo z ideologickopolitických dôvodov do antológie ani tento autor nemohol zaradit' básne v tom čase na Slovensku zakázaných básnikov katolíckej moderny Rudolfa Dilonga a Karola Strmeňa ${ }^{2}$. Pritom aj Hroncove kritériá pri zostavovaní tejto antológie boli predsa subjektívne, podmienené predovšetkým koncepciou "nejakej vlastnej etiky" a zrejme i estetiky, ale i niektorými autorovými individuálnymi obmedzeniami. Myslím tu najmä na Hroncov základný výberový princíp interpretovat' a hodnotit' slovenskú poéziu “len na pozadí celej modernej svetovej poézie” čo bolo vo vel'kej miere obmedzené jeho (ne)znalost'ou jazykov, teda nedostupnost'ou značnej časti svetovej poezie a orientáciou výlučne na jej slovenský, srbochorvátsky a český preklad. V antológii sa ako problematické cíti zvlášt' obdobie 70. a prvej polovice 80. rokov, teda vtedajšia najnovšia tvorba slovenských básnikov, kde vdno autorov nedostatočný časový odstup a tiež i obmedzený, nepostačujúci “materiál” pre dôkladnejšie interpretovanie a zhodnotenie.

Vtedajšie Hroncovo sústavné a súbežné čítanie slovenskej a srbskej literatúry, predovšetkým poézie, dokumentujú jeho "komparatívne” literárnokritické štúdie o súdobych slovenských a srbských básnikov uverejňované v 70. rokoch časopisecky, a nekôr i v knihe Svet básnického obrazu (Hronec, 1988). Už aj z výberu básnikov, ktorých poéziu rozoberal a porovnával, evidentné je Hroncovo uprednostňovanie srbskej poézie klasickej inšpirácie, respektíve srbského neosymbolizmu (Jovan Hristić, Božidar Milidragović, Borislav Radović a Milutin Petrović) a slovenského konkretizmu či senzualizmu (Ján Buzassy, Ján Šimonovič, Ján Stacho, Jozef Mihalkovič), ale aj jeho úsilie v poéziách a poetikách týchto básnikov najst' ak nie i spoločné, tak aspoň kompatibílne znaky. Vplyv a praktické uplatnenie tohto Hroncovho "komparatívneho projektu" vidno aj v jeho básnickej tvorbe, predovšetkým v zbierke Hranica, ktorú možno vnímat' ako svojrázny básnikov experiment; pokus o skĺbenie poetík srbskej poézie klasickej inšpirácie respektíve srbského neosymbolizmu a slovenského senzualizmu.

Podl'a slov jej autora zaradením týchto básnikov, antológia by síce mohla byt' vytlačená, no nemohla by sa distribuovat' vo vtedajšom Československu. 
Názov knihy Svet básnického obrazu jednoznačne signalizuje Hroncovu prvoradú literárnokritickú zameranost' na poéziu; ak nepočítame jeho denníkove záznamy, zvlášt' knihu Algol (Hronec, 2001), v ktorej dôkladne prezentoval i svoje náhlady na prózu, literárnokritické texty o próze tento autor píše menej sústavne ako o poézii. Výnimkou sú recenzie próz nositel’ov Nobelovej ceny, ktoré Hronec sústavne uverejňoval koncom 60. a 70. rokoch v časopise Hlas l'udu, a neskôr publikoval i v knižočke Nobelove deti (Hronec, 2002) a tiež aj jeho aktívne zapájanie sa do polemík o slovenskej vojvodinskej próze v 70. a 80. rokoch minulého storočia (Jazvy na Jazvách, Naša polemika o próze z roku1981, Recidivy kritického realizmu, Ešte niekol'ko slov o románe Lámanie chleba Miroslava Kriváka), kde vel'mi kriticky reagoval najmä na, ako to on vtedy zhodnotil, recidivy kritického realizmu v súdobej prozaickej tvorbe vojvodinských Slovákov. Tento Hroncov relatívny literárnokritický "nezáujem" o prózu ilustruje i údaj, že popri tol'kých antológií, chrestomatií a výberov z poézie jednotlivých básnikov, tento autor nezostavil ani jednu antológiu prózy. Ilustratívna v tomto ohl'ade je napríklad i jeho štúdia Úskalia lyrizácie (Hronec, 1983) napísaná o Labáthovom modernistickom románe Dial'ky, v ktorej si však Hronec všímal predovšetkým lyrizačné tendencie v tomto románe, ktoré mali potvŕdit' jeho tézu o Labáthovej primárnej básnickej tvorivej senzibilite.

Hroncovo sústavné kritické čítanie poézie v druhej polovici 70. a prvej polovici 80. rokov 20. storoči je inšpirované predovšetkým fenomenologickou filozofiou Edmunda Husserla a literárnou "vedou" inšpirovanou fenomenológiou Romana Ingardena. Najvýraznejšie sa to prejavuje v prvej stati knihy Svet básnického obrazu "fenomenologického" pomenovania $V$ híbke obrazu, kde Hronec zaradil pät' rozborov básní, v tom čase najvýznamnejších slovenských vojvodinských básnikov: Pal'a Bohuša, Andreja Ferku, Jána Labátha, Michala Babinku a Juraja Tušiaka. Vo svojom kritickom čítaní poézie, ktoré vtedy vnímal ako "cvičenie na zdíhavej ceste osvojovania si fenomenologického spôsobu pertraktovania daného literárneho diela" Hronec sa usiluje, v súlade s jedným so základných Husserlových fenomenologických postulátov, "konfrontovat' vlastnú skúsenost' a obsah vlastného vedomia s textom básnika” (Hronec, 1988 : 16). Robí to zrejme v presvedčení, že estetické hodnoty existujú objektívne, nezávisle od subjektívnych, individuálnych perspektív hodnotenia, respektíve od kontetxu, v akom sa to hodnotenie uskutočňuje. Práve táto husserlovská viera v imanentné hodnoty a objektívnu pravdu, a zároveň i jeho kritika poznávacieho relativizmu, perspektivizmu, konštruktivizmu a pragmatizmu, bola, a ešte stále zrejme je, aj v základoch Hroncovho kritického čítania a prehodnocovania slovenskej literatúry, predovšetkým poézie, realizovaného najmä prostredníctvom početných antológií slovenskej poézie, ktorými tento literát chcel poukázat' na tie básne, ktoré podla neho majú imanentnú, teda objektívnu, "nestarnúcu" estetickú hodnotu. To znamená, že v súlade s touto filozofiou, literárny kritik pri rozbore textu neutvára, neprodukuje význami a hodnoty, ale ich fenomenologickou intuíciou len objavuje 
a následne pomocou eidetického opisu ${ }^{3}$ prezentuje. Avšak aby sa mu celý tento postup vydaril, literárny kritik musí "vyzátvorkovat" kontext, v ktorom sa takýto rozbor realizuje, čo sa ukázalo, sčasti aj na príklade Hroncových fenomenologických rozborov, ako $\mathrm{v}$ celej tejto metóde najproblematickejšie a t'ažko uskutočnitel'né. No aj napriek tomu, že vtedy, ale i neskôr, fenomenologickú metódu najčastejšie neaplikoval v úplnosti, čiže v jej pôvodnej, “čistej” podobe, tieto rozbory poézie, v tom čase najaktuálnejších srbských a slovenských, respektíve slovenských vojvodinských básnikov, sú dokladom nielen Hroncovej zorientovanosti v súdobých literárnych a literárnokritických tendenciách, ale i jeho výnimočnej básnickej senzibility, interpretačnej zručnosti, dôslednosti a presvedčivosti.

V tomto smere Hronec pokračoval i v monografii Generácia vo vlastnom tieni (Hronec, 1990), do ktorej zoskupil štúdie ${ }^{4}$ o poézii slovenských vojvodinských básnikov, narodených na prelome 20 . storočia, ktorí do literatúry naplno vstúpili v prvej polovici 70. rokov 20. storočia. V básnickej tvorbe Miroslava Demáka, Jozefa Klátika, Michala Dugu, Zlatka Benku a Miroslava Dudka Hronec videl mnohé spoločné, alebo aspoň kompatibílne prvky, čo ho podnietilo k dôkladnému rozboru ich poézie a následne i k vypracovaniu akejsi invariantnej skupinovej poetiky. Okrem toho Hronec týchto básnikov do určitej miery pocitoval aj ako svojích literárnych nasledovatelov, takže podobne ako čo "zúčtoval" so svojími literárnymi otcami, v literárnokritických textoch zaradených do tejto knihy sa "vyporiadúval" i s vlastnými literárnymi synami. Avšak, vekový rozdiel medzi Hroncom a básnikmi zaradenými do generácie vo vlastnom tieni $i^{5}$ bol relatívne malí, čo do určitej miery vysvel'uje i značnú blízkost' poetík týchto básnikov a samého Vít’azoslava Hronca. Možno i preto v úvodnej stati pomenovanej Po rokoch: stretnutie s generáciou Hronec sa "samokriticky" priznáva, že rozbor poézie básnikov generácie vo vlastnej tieni vo vel'kej miere realizoval i "z aspektu vlastnej generácie", čiže "na pozadi vlastnej poetiky". Vidno to najmä pri definovaní hlavného postulátu skupinovej poetiky tejto generácie, podla Hronca obsiahnutého v obraze vrhača disku v siedmej časti poémy Miroslava Dudka Vinobranie, ktorý možno vnímat' ako "zamerania celej generácie na realitu mimo básnického subjektu, prinajmenšom na poznanie tých druhých, ktorí nie sú mnou”, čo je v podstate celkom v súlade i s Hroncovým uprednostňovaným eliotovským postulátom neosobnej poézie.

Pripomienky, zvlášt' voči načrtnutému invariantnému modelu poézie týchto básnikov, čiže "určitému nadindividuálnemu útvaru, ktorý možno nazvat' skupinovou alebo generačnou poetikou”, ktorý Hronec "skonštruoval” z desiatích

3 V tomto bode vidno i zjavnú paralelu s Eliotovým tzv. objektívnym korelátom, ale i s postulátmi tzv. neosobnej poézie, ktoré Hronec i vo svojej vlastnej básnickej tvorbe sústavne uprednostňoval a využíval.

4 Okrem úvodného textu z roku 1988, všetky ostané štúdie v knihe vznikali a boli časopisecky publikované v rozpätí rokov 1977-1982.

5 Toto pomenovanie Hronec prevzal od srbského básnika a literárneho kritika Jovana Zivlaka, ktorý tak označil generáciu básnikov v srbskej literatúre, ktorá nemala svojho kritika, takže zostala, obrazne povedané, vo vlastnom tieni.

6 Kde okrem neho patria i Michal Harpáň a Viera Benková. 
spoločných znakov ich poézie, mali jednak niektorí príslušníci tejto generácie, predovšetkým Miroslav Dudok, ktorý Hroncovi zazlieval určitú sebaprojeciu do načrtnutej skupinovej poetiky, ale i kritik Michal Harpáň, ktorý síce ako dôsledný štrukturalista, nemal výhrady voči principu invariantného modelu literatúry, no predsa od jeho autora očakával prísnejšiu "terminologickú disciplínu" a väčšiu “systematickost'v zorad'ovani syntetizujúcich kritérií" (Harpáň, 1991 : 55). O Hroncovom uvedomovaní si dočasnosti a relatívnosti nielen spoločných skupinových poetík, ale i generačného zoskupovania sa, svedčí druhá čast' tejto monografie, kde jej autor prostredníctvom rozborov niektorých neskorších kníh príslušníkov generácie vo vlastnom tieni, zobrazil evidentný, pritom zrejme i nevyhnutný proces divergencie generačnej poetiky: "Generácie konajú svoju funkciu len dovtedy, kým sa dvaja traja najtalentovanejši ako autori a básnické osobnosti nevyhrania; po tom čine generácia vstupuje do herbária literárnej histórie”. Najväčší význam a prínos Hroncovej knihy o tejto generácii slovenských vojvodinských básnikov je však v jej dôkladnom, na momenty až minucióznom, pritom nealibistickom rozbore poézie, realizovanom sčasti i komparatívne z aspektu ich trojkontextového zapájania sa do slovenskej, slovenskej vojvodinskej a srbskej literatúry. Tieto Hroncove interpretácie mali iste značný podnecujúci význam nielen pre týchto mladých, vtedy začínajúcich básnikov, ale aj pre celkovú slovenskú vojvodinskú poéziu, ktorá $\mathrm{v}$ tom čase, teda $\mathrm{v}$ druhej polovici 70 . a $\mathrm{v}$ prvej polovici 80 . rokov minulého storočia, dosahovala tvorivú kulmináciu a signalizovala i určitú poetologickú pluralitu, čoho najexplicitnejším dokladom bolo pravé takéto generačné zoskupovanie.

Pluralizácia literárneho života vojvodinských Slovákov a súbežné pôsobenie niekol'ko generácií literátov, spolu so značnou politicko-ideologickou liberalizáciou totalitnej juhoslovanskej spoločnosti v 80. rokoch minulého storočia, umožnili a podnietili názorovú a poetologickú viachlasnost', vyúst’ujúcu neraz i v ozajstné literárne polemiky. "Polemické situácie" sa síce v slovenskom vojvodinskom literárnom živote nazerali už i skôr, najmä 60. a 70. rokoch minulého storočia, hlavne v koncepčných, ale i osobných sporoch medzi Jánom Kmetom a Michalom Babinkom, no kulminovali až v 80. a začiatkom 90. rokoch 20. storočia v priam frontálnom zraze medzi podmienečne povedané tradicionalistami a modernistami v slovenskej vojvodinskej literatúre.

Na rozdiel od svojho rovesníka Michala Harpáňa, ktorý ku kritickému čítaniu literatúry pristupoval nekompromisne, no najčastejšie empaticky, a v podstate $\mathrm{i}$ nepolemicky, Hroncov postoj k literatúre a k literárnym problémom bol, a ešte stále je, výrazne vášnivý a polemický, čo najlepšie vidno z jeho početných polemík, najmä tých z 80 . rokov s Jánom Kmetom. Tieto polemiky boli predovšetkým literárneho rázu, no $\mathrm{v}$ úzadí koncepčného rozdielu medzi zjednoduchšene povedané Kmet'ovým tradicionalizmom a Hroncovým modernizmom, prečnievali 
i ideologické rozdiely ${ }^{7}$, ale aj ích osobné súperenie o vedúcu pozíciu vo vtedajšom literárnom živote vojvodinských Slovákov.

Prvá taká polemická situácia, v ktorej sa zúčastnili, Kmet’ priamo, no Hronec len nepriamo, udiala sa začiatkom 70 . rokov minulého storočia a bola vyvolaná Kmetovým kritickým čítaním Hroncovej poézie, na ktoré polemicky reagoval Michal Babinka obviňujúc Kmet’a, okrem iného, i zo ždanovizmu. ${ }^{8}$ Neskôr, v roku 1974, ked' Kmet' vo vydavatel'skej recenzii negatívne zhodnotil zbierku básní Michala Babinku Majster, dielo, ty a tým spôsobom znemožnil jej vydanie, Hronec polemicky reagoval v zatial' nepublikovanom liste Michalovi Babinkovi ${ }^{9}$. V tom istom roku ked’ na prezentácii Bohušovej knihy básni Časom dôjdeme v Báčskom Petrovci Ján Kmet' prečítal v podstate negatívnu recenziu tejto zbierky, Hronec napísal polemicky intonovaný text Môj nesúhlas, ktorý však uverejnil až roku 2003 (Hronec, 2003). Neuverejňovanie, respektíve oneskorené uverejňovanie Hroncových reakcií na Kmetove texty jednoznačne svedčí o vtedajšej dominantnej pozícii Jána Kmet’a v slovenskom vojvodinskom literárnom živote, o jeho literárnej, ale zrejme i politicko-ideologickej autorite, ktorá jednoducho nedovol'ovala vtedy mladému Hroncovi s ním sa otvorene a polemicky konfrontovat'.

Avšak už začiatkom 80. rokov minulého storočia situácia sa v tomto ohl'ade značne pozmenila predovšetkým tým, že sa literárny život vojvodinských Slovákov ideologicky značne uvol'nil a názorovo i pluralizoval, takže si aj mladšie, modernisticky orientované generácie spisovatel'ov a literárnych kritikov mohli vybojovat' výsadnejšie a vplyvnejšie pozície, čo zrejme umožnilo i prvú v úplnosti realizovanú, teda publikovanú polemiku medzi Kmet’om a Hroncom. Polemika vznikla roku 1981 ked' Hronec v texte $O$ pointách a iných chúlostivých veciach $v$ našej poézii (Hronec, 1981) polemicky a obrane reagoval na Kmet'ov text Pointa $v$ modernej a nemodernej básni (Kmet', 1981), v ktorom tento priam pamfleticky zautočil na vtedy najmladšiu básnickú generáciu vojvodinských Slovákov, tzv. generáciu vo vlastnom tieni, a tým vlastne vo vel'kej miere i na celkovú modernistickú koncepciu literatúry a kultúry. Vo svojej reakcii, len navonok zmierlivej, Hronec spochybnil a vyvrátil, argumentovane a početnými príkladmi, základné Kmet'ove kritické pripomienky, najmä tie o dôležitosti pointy respektíve dížky básne pre jej estetickú hodnotu, a na ten spôsob vlastne obhajovall nielen tvorbu vtedy mladých slovenských vojvodinských básnikov, ale i modernú koncepciu poézie, respektíve literatúry. Avšak tri roky neskôr Kmet’ov text Tvorivé tendencie a umelecké dosahy súčasnej vojvodinskej literatúry (Kmet', 1983), už vyvolal ovel'a prudkejšiu Hroncovu polemickú reakciu v texte Recidivy bezbrehého impresionizmu v texte Jána Kmet’a Tvorivé tendencie a umelecké dosahy súčasnej

Ktoré samozrejme v totalitnej spoločnosti nemohli byt' nastolené priamo, ale len v náznakoch, či v „šifrách“.

8 Vyprovokovaný Kmetovým, „čítaním“ poézie vtedy mladého Vítazoslava Hronca v texte Rozličné básne Vitazoslava Hronca, Babinka reagoval dvomi polemicky výrazne vyhrotenými textami: Pro et contra (Babinka, 1972a) a Pro et contra II (Babinka, 1972b).

9 List je zaradený do zatial' nepublikovanej knihy Hroncových polemík zo 70. a 80. rokov minulého storočia pomenovanej Na lôžku so súdružkou polemikou. 
vojvodinskej literatúry, prečítanom na literárnej porade roku 1984, no uverejnenom v Novom živote až roku 1989 (Hronec, 1989). Do tohto kontextu možno dat' aj Hroncov polemický text Recidivy kritického realizmu (Hronec, 1984a) a diskúsny príspevok Ešte niekol'ko slov o románe Lámanie chleba Miroslava Kriváka (Hronec, 1984b), kde sa tento autor zmienil, výrazne kriticky a polemicky, o vtedy publikovanom Krivákovom románe Lámanie chleba, ale zároveň i o spiatočníckych tendenciách v súdovej slovenskej vojvodinskej próze, aké v podstate aj Ján Kmet' vo svojej koncepcii literatúry uprednostňoval a podporoval.

Rozmach slovenskej vojvodinskej literaterárnej tvorby v 80 . rokoch 20 . storočia, predovšetkým jej pluralizácia a čiastočne i odpútanie sa od prísnej ideologickopolitickej kontróly, produkoval i dynamickejší literárny život vojvodinských Slovákov, čoho kulmináciou bola vel'ká polemika z roku 1990, uskutočnená v Novom živote a v týždenníku Hlas l'udu, v ktorej sa popri Kmetovi a Hroncovi zúčastnili aj Pal’o Bohuš, Samuel Fekete, Miroslav Demák, Zoroslav Spevák, ako aj niektorí iní literáti a novinári. Pre túto polemiku je príznačné, že začiatočný spor medzi zástancami podmienečne povedané tradičnej a modernej koncepcie literatúry čoskoro vyustil v priam frontálnu konfrontáciu rozličných kultúrnych a spoločensko-ideologických modelov ${ }^{10}$ a konečne i $\mathrm{v}$ osobné zúčtovanie a svojrázne inkasovanie starých dlhov ${ }^{11}$. Bola to však už definitívna porážka tradicionalistickej romantizujúco-folklorizujúcej koncepcie literatúry a jej hlavní propagátori (Karol Burčiar, Samuel Fekete a sčasti i Ján Kmet'), sa prakticky už nevrátili do literárneho života vojvodinských Slovákov. Aj neskôr sa v slovenskej vojvodinskej literatúre občas zjavovali náznaky polemickych situácií, v ktorých sa najčastejšie zúčastňoval i Vít’azoslava Hronca (polemiky so Zoroslavom Spevákom, Miroslavom Kaňom, Samuelom Čemanom a najmä polemika so Samuelom Boldockým...), no bol to už len prejav individuálnych rozdielov v niektorých parciálnych literárnych problémoch a otázkach, ktorý podstatnejšie nezasahoval do literárneho života vojvodinských Slovákov.

$\mathrm{V}$ poslednom desat'ročí 20. a v prvom desat'ročí 21. storočia Hronec sa v kritickom čítaní literatúry prakticky v úplnosti preorientoval na žánre eseje a úvahy, čo jasne naznačuje jeho citlivé načúvanie ,tepu“ doby, prejavujúce sa v tomto prípade $\mathrm{v}$ uplatnení typickej postmodernej žánrovej hybridizácie, teda $\mathrm{v}$ akejsi tvorivej symbióze beletrie, literárnej kritiky a filozofie. Najvýpuklejšie to vidno v jeho denníkoch, ktoré síce časopisecky začal uverejňovat' ešte $\mathrm{v}$ druhej polovici 80. rokov, no knižne až koncom 20. a začiatkom 21. storočia, podpisujúc ich menom svojej literárnej postavy Vladimíra Lutrova. Hronec zatial' publikoval štyri kníhy denníkov: Stretnutie s Minotaurom (1964-1966), Nebo nad Helespontom (1967-1970), Lemnos, Lemnos (1971-1984) a Zreničkou Perzefony (1985-1995), ako

\footnotetext{
10 Polemika sa uskutočňovala vo formálne pluralitnej, demokratickej spoločnosti, no v ovduší vtedajšieho vel'mi silného populisticko-nacionalistického režímu Slobodana Miloševića.

11 Bolo to svojráznym pokračovaním tzv. „prípadu Blatno“, čiže subverzívneho happeningu v garáži Pala Bohuša 19. júna 1981 roku, ktorý vyvolal polemickú reakciu nielen kultúrnych tradicionalistov, ale i ideologických „strážcov“.
} 
aj dva denníky o próze: Algol (Denník o románe Plný ponor 1988-1999) a Alchýmia fiktívného (Záznamy na okraj knih Sklený vietor a Pán vzduchu a králov syn Vit’azoslava Hronca), knižne publikované pod spoločným menom Algol . Podl'a slov samého Hronca, tieto uverejnené denníky sú vlastne len „literárnou“ častou jeho každodenných záznamov, ktoré tento autor rokami sústavne písal a píše. Pri takýchto autorom upravovaných denníkoch sa nevyhnutne nastoluje otázka ich evidentnej selektívnosti, teda i otázka miery autorového spätného „retušovania“ či „,enzurovania“. Avšak pre tieto denníky vnímané ako kritické čítanie literatúry, to je už vcelku nepodstatné, lebo one svoju literárnokritickú funkciu začínajú splňat' $\mathrm{v}$ takej podobe, $\mathrm{v}$ akej sú publikované, bez ohl'adu na ich eventuálnu odlišnú primárnu či „originálnu“ verziu.

Najväčšia čast' Hroncových denníkových zápiskov sa vztahuje na autorovo komentovanie, citovanie, parafrazovanie a často i intepretovanie svojej literárnej lektúry, teda prečítaných diel slovenskej, srbskej a svetovej literatúry. Žánrovo, tieto časti denníkov možno vnímat' ako literárnokritické interpretácie, eseje a úvahy, ktoré sú predovšetkým dokladom Hroncovej intelektuálnej zvedavosti a sčítanosti, no v ktorých sa odzrkadl'uje i jeho vzt’ah $\mathrm{k}$ literatúre a $\mathrm{k}$ umeniu, a zároveň i proces výstavby literárnej poetiky a životnej filozofie. Na druhej strane, tieto literárnokritické interpretácie a esejistické syntetizovanie, často však len načrtnuté, alebo zamerané na parciálne časti literárneho textu respektíve literárneho problému, boli zrejme i svojráznym „cvičením“ pre Hroncovu súbežne publikovanú literárnokritickú tvorbu.

Značnú čast' tychto denníkov zaberá i Hroncovo sebareflexívne uvažovanie o vlastnej tvorbe; od poetologického uvažovania o uprednostňovanej a budovanej poetiky, cez zobrazovanie samotného procesu literárnej tvorby, najmä sústavného dotvárania a vylepšovania jednotlivých textov až po dôkladnú autointerpretáciu niektorých vlastných literárnych textov. Tak napríklad v denníkovom zázname z 13. októbra 1988 neskôr uverejnenom v knihe Zreničkou Perzefony, Hronec sa zamýšl’a nad možnostiami a spôsobmi poznania a na konci v zátvorke dopisuje: "Toto by sa dalo rozvrhnút aj do veršov". Práve to Hronec aj urobil a tento prakticky nepozmenený zápis z denníka neskôr rozpísal do veršov a uverejnil ako báseň pomenovanú Kol'ko má kosti vel'ryba a uverejnenú v zbierke Prázda streda.

Táto Hroncova sebareflexívnost' a autointerpretačnost sa však najvýraznejšie prejavila v jeho denníkoch o próze v knihe Algol, ktoré vznikali súbežne s jeho intenzívnym písaním prozaických knih Pán vzduchu a králov syn a Plný ponor, kde tento autor, analyzujúc predovšetkým vlastné písanie prózy, ale i prozaickú tvorbu iných autorov, vo vel'kej miere načrtol uprednostňovanú poetiku prózy, ale zároveň i prakticky dokumentoval typický postmoderný tvorivý posun od vymýšlania fiktívneho príbehu k rekonštrukcii samotného pribehu písania.

Typickým prejavom takejto postmodernej symbiózy či spolutvorenia spisovatel'a a literárneho kritika je i Hroncova autorinterpretácia básne Hranica I príznačného pomenovania Nulový stupeň rétoriky (Hronec, 2008). Podla slov samého autora, na takéto gesto ho prinútilo uvedomovanie si hermetickosti básnického cyklu 
Hranica I, ktorý literárna kritika aj napriek dodatočne uverejneným vysvetl'ujúcim poznámkam predsa nevedela adekvátne interpretovat'. Takýmto zásahom do literárnej komunikácie, pritom bez ironického odstupu, Hronec-autor do určitej miery popiera Hronca-literárneho kritika, čiže jeho uprednostňovanie fenomenologickej zásady literárnokritickej usmernenosti na samotný text, sprevádzané pritom závezným vyzátvorkovaním všetkého mimo interpretovaného textu. Hroncova „nedôvera“ voči čitatel'ovi respektíve literárnemu kritikovi je zároveň aj v kolízii s celkovou postmodernou poetikou v akej táto autointerpretácia vznikala, teda s otvorenostou, viacvýznamovostou a dialogickost'ou literárneho textu, ktorá proces tvorby významov posúva zo spisovatel'a na čitatel'a, respektíve literárneho kritika. V tomto kontexte odpozorovaná, potom aj táto Hroncova autointerpretácia je vlastne len d’alšie kritické čítanie literárneho textu, konkrétne básnického cyklu Hranica I, ktoré sa zapája do intersubjektívného dialógu respektíve konsenzu významov a hodnôt. Avšak od literárnokritického či poznávacieho, Hroncova knižočka Nulový stupeň rétoriky má podl'a mňa ovel’a väčší beletristický význam, lebo sa číta ako zaujímavý „hybrídny“ postmoderný text.

Značná čast' Hroncových denníkových záznamov je zameraná aj na zobrazenie a komentovanie slovenského, najmä slovenského vojvodinského, a sčasti i juhoslovanského (neskôr srbského) literárneho života. To znamená, že okrem autobiografického a literárnokritického, Hroncove denníky majú i značný literárnohistorický ráz; sú to svojrázne Hroncove individuálne ,,apokrifné“ dejiny slovenskej vojvodinskej literatúry, ktoré hovoria o najvýznamnejších udalostiach, osobnostiach a dielach $\mathrm{v}$ slovenskom vojvodinskom literárnom živote za posledných pät'desiat rokov, podané z perspektívy jedného z jeho priamých, pritom iste aj najvýznamnejších aktérov a nanajvýš kompetentných pozorovatel'ov a zapisovatelov.

V kontexte slovenskej vojvodinskej literatúre dôležité sú i Hroncove početné eseje a úvahy, ktoré tento autor začal intenzívne časopisecky publikovat' koncom 20. storočia a neskôr ich uverejňovat' v knihách Pokušenie svätého žánru (Hronec, 2004a), Viacrukost' poézie (Hronec, 2012), Práce a dni (Hronec, 2004b) a Povetrie nazajtra (Hronec, 2007). Hroncove eseje sú iste vrcholením nielen jeho celkového literárneho pôsobenia, ale i literárnej tvorby vojvodinských Slovákov, lebo sa v ních autorovi podarilo esejistickou „skratkou“ efektne skíbit’ svoj poetický, rozprávačský, literárnokritický, umelecký a filozofický tvorivý potenciál s výnimočnou erudíciou, rozhladenostou a citom pre tep doby a všetko to prezentovat' v súgestívnom esejistickom prejave. Avšak aj napriek širokému tematickému uhlu záberu, základné Hroncovo východisko vo väčšine týchto esejí bola poézia, čo je d’alším dokladom jeho prvoradej poetickej tvorivej povahy. V týchto esejách autor uvažuje, rozoberá a hodnotí rozličné témy a problémy (zlo, vzt’ah etiky a estetiky, cenzúra a autocenzúra, osud enklávového spisovatel'a, moc poézie, boh, gýč, melanchólia, smrt', ideológia a umenie...), no robí to najčastejšie na úzadí poézie, ktorej prisudzuje najväčší poznávací potenciál, vyrovnávajúci 
sa, a často i prevyšujúci poznanie vedecké či filozofické. Pre túto esejistickú, zatial' poslednú Hroncovu tvorivú fázu, ktorá v značnej miere poznačila i jeho početné historizujúce predslovy $\mathrm{k}$ antológiám a chrestomatiám, príznačné je stupňovanie autorovej kritickosti, nekompromisnosti, často až výlučnosti. Prišlo to k slovu najmä v polemikách s Miroslavom Kaňom, Samuelom Čemanom a Samuelom Boldockým, ale aj vo svojráznej literárnokritickej „detrónizácie“ niektorých významných slovenských spisovatel’ov (Ján Smrek, Pavel Ország Hviezdoslav, Ján Čajak...). Avšak Hronec v podstate aj tu zostáva verný svojim začiatočným východiskom a postojom v kritickom čítaní literatúry, s tým rozdileom, že ich teraz už obhajuje prakticky bez akýchkol'vej ideologických zábran a osobných ohl'adov. Dotvára tak svoj celoživotný literárno-umelecko-filozofický projekt, ktorý síce aspoň formálne necháva otvorený a zapojený do nejakého hypotetického intersubjektívneho dialógu, no evideneté je, že niekde hlboko v sebe, modernisticky totalizujúco zostáva neoblomne presvedčený v nespochybnitel'nost' tohto svojho konštruktu a ním uprednostnených (literárnych) hodnôt.

Začiatkom 21. storočia Hronec pokračoval ešte intenzívnejšie v započatej revalorizácii slovenskej (vojvodinskej) básnickej tradície, čo vidno aj z faktu, že v roku 2005 v Novom živote uverejnil prvú verziu či svojrázne pokračovania knihy Poézia vojvodinských Slovákov, pomenované teraz Antológia slovenskej vojvodinskej poézie (Hronec, 2007). V tejto antológii autor už nebol nútený na žiadne kompromisy a ohl'ady, takže pri interpretovaní, hodnotení a výbere básní mohol postupovat' výlučne v súlade so svojími pevne stanovenými estetickými kritériámi a presvedčeniami. Umožnila mu to predovšetkým demokratizovaná, liberálna spoločnost', pritom iste aj vlastné výsadné, priam bardovské postavenie v literárnom živote vojvodinských Slovákov, ale azda najviac presvedčenie, že klasicizujúce tendencie v slovenskej vojvodinskej poézii, ktoré musel v predošlej knihe konštituovat', no niekedy i konštruovat', až ,,nadúživat'“, teraz už ,,nielenže získali domovské právo, ale sa stali jej dominantným prúdom". Práve preto ani neprekvapuje dominujúci postoj zadost'učinenia a vítazstva, s akým Hronec v tejto antológii doplňuje, čiastočne i koriguje, no vo vel'kej miere vlastne potvrdzuje svoju začatú revalorizáciu slovenskej vojvodinskej básnickej tradície. V kontexte takejto Hroncovej „euforickosti“ možno potom pochopit’ aj jeho úsilie zavŕšit', položit' bodku na tento proces ,,vnucovania vlastnej farby svojmu okoliu“, ktorý sa podl'a tohto autora pomaly už ,stáva vecou literárnej histórie“. Takéto Hroncovo „betonovanie“ básnickej tradície vojvodinských Slovákov je zrejme v kolízii s teoretickým postulátom anglo-amerického básnika i kritika Thomasa Stearna Eliota, podl'a ktorého aj sám Hronec vlastne najviac uskutočňoval prehodnocovanie slovenskej vojvodinskej básnickej tradície, a ktorého postulát $\mathrm{v}$ antológii aj sám citoval: „medzi jestvujúcimi literárnymi pamiatkami vládne ideálny poriadok, ktorý sa tým, že medzi ne vovedieme nové (naozaj nové) dielo, modifikuje.". Prekvapuje to tým viac, že tento dialektický proces Hronec aj prakticky neraz predvádza, ked’ píše o zmenách, aké v jeho vnímaní slovenskej vojvodinskej poézie spôsobilo napríklad prečítanie kompletného tisíctristo 
stranového rukopisu diela Tragédia Tatry Jozefa Podhradského, tiež rukopisnej básnickej zbierky Ked' po hrdinstve Zlatka Benku, ale najmä zbierky básní Kameň na dlani Ladislava Čániho, ktorej prvé čítanie zapríčinilo, podla Hroncových slov, korigovanie výberov „,akmer všetkých našich básnikov“. Avšak takéto, len navonok paradoxné Hroncovo počínanie treba pozorovat' predovšetkým v kontexte silného nátlaku modernistickej harmonizujúcej či totalizujúcej poetiky, ktorá sa prejavuje okrem iného už aj v Hroncovej východiskovej, typicko štrukturalistickej binárej opozícii medzi klasicizujúcou a romantizujúcou poéziou, tiež i v "progresivistickom” chápaní básnickej tradície ako „logicky štrukturovaného vývinového radu" a zrejme i v autorovej fenomenologickej viere v možnost' prostrednítvom interpretácie spoznat' ozajstné, ,nespochybnitel’né estetické artefakty". Popravde povedané, Hronec tento ustanovovujúci proces predsa nezakončuje bodkou, ale obrazne povedané čiarkou, lebo sa zasadzuje za literárnokritický či literárnohistorický intersubjektívny konsenzus, ktorý však dodatočne relativizuje tažko uskutočnitel’ným ,všeobecným súhlasom“ o „,nespochybnitelných hodnotách".

Pozmenená východisková situácia, teda evidentný doplňujúci a čiastočne korigujúci charakter Antológie slovenskej vojvodinskej poézie, spôsobili aj Hroncov odlišný literárnokritiký prístup v jej predslove. Na rozdiel od dôkladného interpretovania básnickej tvorby autorov zaradených do výberu v knihe Poézia vojvodinských Slovákov, ktoré takýmto metodologickým postupom nadobúdalo charakter svojrázneho literárnohistorického prehladu premien celkovej dovtedajšej básnickej tvorby vojvodinských Slovákov, v Predslove k Antológii slovenskej vojvodinskej poézie sa Hronec sústred’uje už len na niektoré kl’účové momenty týchto premien, pričom dôkladnejšie, hlavne esejistickým, na momenty až lakonicko-fragmentárnym a často i výrazne polemickým štýlom nastoluje a analyzuje predovšetkým tie, podl'a neho najpálčivejšie problémy $\mathrm{v}$ poézii vojvodinských Slovákov, aké sú napríklad potreba (re)definovania slovenského vojvodinského literárneho kontextu a s tým súvisiace zapájanie do antológie Pavela Jozefa Šafárika (no nie i podobne pôsobiacého Františeka Lipku), potom problém manierizmu v súčasnej poézii vojvodinských Slovákov, alebo i potreba intersubjektívného hodnotiaceho konsenza v našej súčasnej, podl'a Hronca neexistujúcej literárnej kritike.

Na celoživotnom projekte budovania slovenskej vojvodinskej básnickej tradície Hronec pokračoval i v antológii Odfotografovat' odchod odinakial' (Hronec, 2008), do ktorej zaradil výber z poézie uverejňovanej v rokoch 1970 až 2004 v rubrike Rozlety v mládežníckom časopise Vzlet. Ciel’om tejto antológie je podl'a slov jej zostavatel'a "aby poézia vojvodinských Slovákov bola lepšie pochopená ako vysoko štrukturovaný celok, časti ktorého sú medzi sebou vzájomne prepojené a pospájané.". V tomto svojráznom doplňujúcom dodatku k Antológii Slovenskej vojvodinskej poézie Hronec už v príslovečnej prísnej hodnotiacej selekcii, založenej na dôkladných a dôsledných esteticko-literárnych kritériách, vybral najvyspelejšie básne respektíve verše 67 básnikov. Vel'ká väčšina z týchto básnikov neskôr 
rezignovala na písanie poézie, no niektorí z ních pokračovali v literárnej tvorbe a stali sa významný slovenskí vojvodinskí spisovatelia (Zlatko Benka, Miroslav Dudok, Zoroslav Spevák, Tomáš Čelovský, Ján Salčák, Miroslava Kaňa, Miroslav Šipický, Miroslava Dudková...). V obsiahlom Predslove Hronec podáva literárnohistorický prehl'ad básnickej tvorby mladých začiatočníkov v slovenskej vojvodinskej literatúre, usilujúc sa pre štyry obdobia kryjúce sa s jednotlivými desat'ročiami a určené jednak literárnymi, jednak spoločensko-politickými činitel'mi, vydiferencovat' a definovat' dominantné poetologické znaky a ilustrovat' ich vlastnými rozbormi reprezentatívných básní. To čo však v takomto Hroncovom ustanovujúcom úsilí môže prekážat' je jej absolutizujúci charakter, explikovaný v samom závere Predslovu ("V knihe však nie je ani jedna básěn, ktorú by bolo možné zaradit' do budúcich antológii celkovej našej poézie."), ktorý v podstate popiera potrebu zostavovania nejakej inej antológie, respektíve znemožňuje akýkol'vek intersubjektívny dialógu a konsenzu okolo spoločných hodnôt.

Svoj projekt ustanovovania básnickej tradície vojvodinských Slovákov Hronec, aspoň zatial', ukončil ${ }^{12}$ roku 2010 publikovaním Chrestomatie slovenskej vojvodinskej poézie (Hronec, 2010), ktorá je podl'a slov tohto autora nevyhnutné úzadie, doplňujúce a ozrejmujúce prvé dve antológie. $Z$ tohto aspektu je významný najmä rozsiahly Predslov ku chrestomatii, ktorý svojou literárnohistorickou koncepciou vel'mi presvedčivo, na príklade interpretácií básníckej tvorby prakticky všetkých najvýznamnejších slovenských vojvodinských básnikov, zohl'adňuje celkový obraz premien vyše dvestopet'desiat' rokov dlhej básnickej tvorby vojvodinských Slovákov. $Z$ tejto perspektívy odpozorované treba zvlášt' vyzdvihnút' Hroncovo znalecké zarad’ovanie slovenskej vojvodinskej poézie do širších literárnych kontextov, predovšetkým do kontextu celoslovenskej, potom srbskej, a nie na poslednom mieste i svetovej literatúry. V týchto kontextoch sa Hronec suveréne pohybuje a to nielen $\mathrm{v}$ ich synchronických, ale i $\mathrm{v}$ diachronických rovinách, pričom vel'mi citlivo sleduje zvlášt' štýlové a poetologické premeny literatúry a umenia $\mathrm{v}$ 20. storočí a ich odzrkadlovanie sa v tvorbe vojvodinských Slovákov. V Predslove ku Chrestomatii slovenskej vojvodinskej poézie evidentne kulminuje Hroncovo úsilie usporiadat' slovenskú vojvodinskú básnickú tradíciu do ,logicky štrukturovaného celku“, pričom sa tento autor už neuspokojuje len s literárnym, ale zároveň siaha i za umeleckým, najmä výtvarnym a filozofickým kontextom, lebo mieni, že ,takmer všetci tunajši básnici a veršovci, bez ohl'adu na evidentnú malost' i stiesnenost' prostredia, prostrednictvom svojho viaclingválneho vzdelania neprestajne tvorili v priesečníkoch mnohých svetových literárnych i filozofických vplyvov. “. Aj ked' táto Hroncova priam prepiata potreba usúvstažovat' často, aspoň navonok, vel'mi vzdialené a nesúvislé javy, na prvý pohl'ad vyznieva ako konštrukcia či nadinterpretácia, tento kritik to robí vel'mi sebavedome, zdôvodnene a sugestívne, takže to $\mathrm{v}$ konečnom dôsledku predsa nadobúda celkom presvedčivý a logický význam.

12 Hroncovo kapitálne dielo, ktoré je zatial' len v rukopise, bude Antológia slovenskej poézie, v ktorej sa tento autor pokúsil revalorizovat' celkovú slovenskú básnickú tvorbu. 
Hroncovo dlhoročné prehodnocovanie a ustanovovanie básnickej tradície vojvodinských Slovákov kulminuje knihou Pod klenbou básnickej tradície (Hronec, 2014), do ktorej sú zaradené predslovy z kníh Poézia vojvodinských Slovákov, Antológia slovenskej vojvodinskej poézie a Chrestomatia slovenskej vojvodinskej poézie. Zoskupené na jednom mieste tieto texty nadobúdajú syntetizujúci rozmer svojráznych dejín slovenskej vojvodinskej poézie, alebo obrazne povedané „klenby“ zostrešňujúcej doterajšiu básnickú tvorbu vojvodinských Slovákov, no zároveň anticipujúcu či usmern̆ujúcu aj jej budúci vývin.

Adam Svetlik

\section{DAS KRITISCHE LESEN DER LITERATUR VON VÍŤAZOSLAV HRONEC}

\section{DIE ZUSAMMENFASSUNG}

Im Text wird das kritische Lesen der Literatur von Vít'azoslav Hronec analysiert, das einen wichtigen Platz nicht nur in seiner literarischen Tätigkeit, sondern auch in der Literatur der Slowaken von Vojvodina einnimmt. Die ersten literarisch-kritischen Interpretationen des gegenwärtigen slowakischen poetischen Schaffens publizierte Hronec in den 60er Jahren des 20. Jahrhunderts. Seitdem versucht er bis heute, mit seinem kritischen Lesen die Qualität der gesamten slowakischen Literatur in der Vojvodina zu verbessern und die Weiterentwicklung der Literatur zu fördern. Von großer Bedeutung sind seine Anthologien der slowakischen Poesie aus der Vojvodina und allumfassende historisch-literarische Vorworte, die als eine ganz besonders artige Geschichte der slowakischen Poesie in der Vojvodina gelesen werden könnten. Der methodologische Hauptausgangpunk von Hronec wurde zuerst von der Phänomenologie inspiriert. Sein kritisches Lesen wurde aber später, vor allem in der postmodernen Schaffensperiode in der Jahrhundertwende, von einer essayistischen Ausdrucksform und einer breiten kulturspezifischen Perspektive geprägt. Die hohe Gelehrsamkeit und ein Gespür für den Zeitgeist kommen in seiner breiten kulturologischen Perspektive recht gut zum Ausdruck.

Schlusselwörter: Vít’azoslav Hronec, das kritische Lesen der Literatur, Antologie, Phänomenologie, Essay 


\section{LITERATÚRA}

Babinka, M. (1972a). Pro et contra. Nový život, 3, 273-274.

Babinka, M. (1972b). Pro et contra II. Nový život, 4, 376-377.

Harpán̆, M. (1991). Variácie na tému generačných procesov v našej literatúre, Nový život, 1-2, 52-56.

Hronec, V. (1974). Poézia vojvodinských Slovákov (od 18. do 20. storočia). Nový Sad : Obzor. Hronec, V. (1979). Za poetikou. Nový Sad : Obzor.

Hronec, V. (1981). O pointách a iných chúlostivých veciach v našej poézii. Nový život, 4, 372-375.

Hronec, V. (1983). Úskalia lyrizácie. Nový život, 2, 181-186.

Hronec, V. (1984a). Recidívy kritického realizmu. Nový žiovt, 3, 177-183.

Hronec, V. (1984b). Ešte niekol'ko slov o románe Lámanie chleba Miroslava Kriváka. Nový život, 3, s. 205-206.

Hronec, V. (1986). Antológia slovenskej poézie 20. storočia. Nový Sad : Obzor.

Hronec, V. (1988). Svet básnického obrazu. Nový Sad : Obzor.

Hronec, V. (1989). Recidívy bezbrehého impresionizmu v texte Jána Kmet’a Tvorivé tendencie a umelecké dosahy súčasnej vojvodinskej literatúry. Nový život, 7-8, 494.

Hronec, V. (1990). Generácia vo vlastnom tieni. Nový Sad: Obzor.

Hronec, V. (2001). Algol. Báčsky Petrovec : Kultúra.

Hronec, V. (2002). Nobelove deti. Báčsky Petroevc : Kultúra.

Hronec, V. (2003). Môj nesúhlas. Nový život, 11-12, 661-662.

Hronec, V. (2004a). Pokušenie svätého žánru. Nadlak - Bratislava : Vydavatel'stvo Ivan Krasko, Vydavatel'stvo ESA.

Hronec, V. (2004b). Práce a dni. Báčsky Petrovec : Kultúra.

Hronec, V. (2005). Antológia slovenskej vojvodinskej poézie. Báčsky Petrovec : Kultúra.

Hronec, V. (2007). Povetrie nazajtra. Nový Sad : Hlas l'udu.

Hronec, V. (2008). Nulový stupeň rétoriky. Stará Pazova : Art centrum Chlieb a hry.

Hronec, V. (2008). Odfotografovat' odchod odinakial'. Nový Sad : Hlas l'udu.

Hronec, V. (2010). Chrestomatia slovenskej vojvodinskej poézie. Bačsky Petrovec : SVC.

Hronec, V. (2012). Viacrukost' poézie. Báčsky Petrovec : SVC.

Hronec, V. (2014). Pod klenbou básnickej tradície. Báčsky Petrovec : SVC.

Kmet', J. (1981). Pointa v modernej a nemodernej básni. Nový život, 4, 345-348.

Kmet', J. (1984). Tvorivé tendencie a umelecké dosahy súčasnej vojvodinskej literatúry. Nový život, 2, 139-146. 